\title{
1 Hydrologic control of carbon cycling and aged carbon \\ 2 discharge in the Congo River basin
}

3 Enno Schefuß $\Re^{1,3}$, Timothy I. Eglinton ${ }^{2,3}$, Charlotte L. Spencer-Jones ${ }^{4, *}$, Jürgen Rullkötter ${ }^{5}$,

4 Ricardo De Pol-Holz ${ }^{6}$, Helen M. Talbot ${ }^{4}$, Pieter M. Grootes ${ }^{7}$, Ralph R. Schneider ${ }^{7,8}$

$5{ }^{1}$ MARUM - Center for Marine Environmental Sciences, University of Bremen, Germany

$6 \quad{ }^{2}$ Department of Geological Sciences, ETH Zürich, Switzerland

$7{ }^{3}$ Department of Marine Chemistry and Geochemistry, Woods Hole Oceanographic Institution,

8 USA

$9{ }^{4}$ School of Civil Engineering and Geosciences, Newcastle University, United Kingdom

$10{ }^{5}$ Institute for Chemistry and Biology of the Marine Environment (ICBM), Carl von Ossietzky

11 University of Oldenburg, Germany

$12{ }^{6}$ GAIA-Antártica, Center for Climate and Resilience Research $(C R)^{2}$, Universidad de

13 Magallanes, Punta Arenas, Chile

$14{ }^{7}$ Leibniz-Laboratory for Radiometric Dating and Stable Isotope Research Kiel, Germany, now

15 at: Institute for Ecosystem Research, Christian-Albrechts-University Kiel, Germany

$16{ }^{8}$ Institute for Geosciences, Christian-Albrechts-University Kiel, Germany

17 *Now at: Department of Geography, University of Durham, United Kingdom

18 The age of organic material discharged by rivers provides information about its

19 sources and carbon cycling processes within watersheds. While elevated ages in

20 fluvially-transported organic matter are usually explained by erosion of soils and 
21 sediments deposits ${ }^{1,2}$, it is commonly assumed that mainly young organic material is 22 discharged from flat tropical watersheds due to their extensive plant cover and rapid 23 carbon turnover ${ }^{3-7}$. Here we present compound-specific radiocarbon data of terrigenous 24 organic fractions from a sedimentary archive offshore the Congo River in conjunction 25 with molecular markers for methane-producing land cover reflecting wetland extent. 26 We find that the Congo River has been discharging aged organic matter for several 27 thousand years with apparently increasing ages from the Mid- to the Late Holocene. 28 This suggests that aged organic matter in modern samples is concealed by radiocarbon

from atmospheric nuclear weapons testing. By comparison to indicators for past rainfall changes we detect a systematic control of organic matter sequestration and release by continental hydrology mediating temporary carbon storage in wetlands. As aridification also leads to exposure and rapid remineralization of large amounts of previously stored labile organic matter we infer that this process may cause a profound direct climate feedback currently underestimated in carbon cycle assessments.

Tropical humid ecosystems are hot spots of terrestrial carbon storage ${ }^{8}$ and large river systems in tropical areas form an important conduit in the global carbon cycle by transporting vast amounts of biosynthetic OM to the ocean ${ }^{9,10}$. Apparent radiocarbon ages of riverine organic carbon are interpreted as the mean time elapsed since biosynthesis, integrating all intermediate storage, transport and mixing processes, and thus considered to reflect the speed of carbon cycling in watersheds. Radiocarbon studies of fluvially-transported OM reveal relatively young ages in tropical areas ${ }^{3-7}$, suggesting rapid carbon turnover, and greater ages in temperate regions with larger influence of geomorphology and soil erosion ${ }^{1,2}$. Among the controlling processes, relative changes in export of contemporary biomass versus erosion of OM from soils or sedimentary rocks (e.g., refs 1,7$)$ as well as storage in intermediate 
reservoirs, such as floodplains and wetlands (e.g., refs 11-13), are discussed. The exact factors controlling the continental residence times of terrestrial OM in tropical watersheds and their response to climatic changes are, however, not yet fully understood.

To provide insight into the response of OM cycling in large tropical watersheds to climatic changes we investigated a sedimentary archive simultaneously recording continental palaeo-climatic changes and variations in terrestrial carbon cycling in the Congo basin.

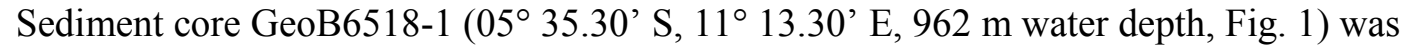
recovered from the Congo deep-sea fan close to the river mouth. The Congo is the second largest river on Earth in terms of drainage basin size (about $3.7 \times 10^{6} \mathrm{~km}^{2}$ ), water discharge ${ }^{14}$ and terrestrial organic matter export ${ }^{15}$. Located in equatorial Africa, it is characterized by low intra- and inter-annual discharge variability ${ }^{16}$. Steep rapids close to its estuary separate the central Congo basin from sea-level influence. A submarine canyon incises the continental shelf, extending from the Congo estuary and leading to rapid transport of discharged material to the deep-sea fan. The ages of terrestrial organic material are therefore considered to reflect retention processes within the river basin. We measured the ${ }^{14} \mathrm{C}$ content of various $\mathrm{OM}$ fractions (total organic matter, microscopic wood fragments, leaf-wax $n$-alkanes, and individual leaf-wax n-alcohols) from several depth intervals of core GeoB6518-1 (Table S2). Using the depositional ages based on radiocarbon dating of planktonic foraminifera (Table $\mathrm{S} 1$ ), radiocarbon contents of $\mathrm{OM}$ fractions were decay-corrected to derive initial radiocarbon contents. The deviation from the past atmospheric ${ }^{14} \mathrm{C}$ content $\left(\Delta \Delta{ }^{14} \mathrm{C}_{\text {initial }}\right.$, see Methods $)$ at the time of deposition can be converted to apparent initial radiocarbon ages. The initial ages of the $\mathrm{OM}$ fractions range from isochronous up to $3,000{ }^{14} \mathrm{C}$ years (Fig. 2a). Notably, initial ages of wood fragments are contemporaneous to or only slightly older than depositional ages in the Early to Mid-Holocene. In contrast, the plant-wax fractions are older and show higher but 
coherent age variability (Fig. 3). This is in accordance with both a rapid transfer of plant debris through the river system under high discharge conditions and the refractory nature and persistence of plant waxes in soils ${ }^{17}$. The aged terrestrial organic contributions strongly influence the age of total organic carbon (TOC) deposited off the Congo River despite its mixed terrestrial and aquatic origin (Fig. 2a). From about 5,000 years before present (BP) all organic components show a similar trend to greater apparent initial ages towards the present. The Congo River has, thus, exported aged OM for the last several thousand years. This finding is in contrast to ${ }^{14} \mathrm{C}$ results from modern fluvial $\mathrm{OM}$ in the Congo River and other tropical river systems, where terrestrial components were found to be mainly contemporary in age $e^{4-7}$. We infer that this discrepancy is caused by the influence of radiocarbon from atmospheric nuclear weapons testing in modern samples, masking their original age. This influence is also detected for the uppermost sample from GeoB6518-1 which exhibits reversals in the $\Delta^{14} \mathrm{C}_{\text {initial }}$ of all OM fractions (Fig. S3). The influence of bomb-derived radiocarbon on modern samples in carbon cycle studies therefore needs to be considered more carefully.

To explain the Holocene age variations we investigated indicators for OM contributions from soils, sedimentary rocks and wetlands, and also considered variable carbon turnover due to changes in river transport, continental temperatures and hydrologic conditions. Previously we showed that the OM of core GeoB6518-1 is predominantly terrigenous with the majority derived from soils ${ }^{18}$. The proportion of soil- versus plant-derived OM estimated by the abundance of membrane lipids from soil-hosted bacteria, however, was relatively invariant through time ${ }^{18}$ (Table S2). While this suggests that relative contribution changes of soilderived $\mathrm{OM}$ due to variable vegetation cover and soil erosion cannot explain the age variations, it does not rule out erosion of deep soil layers and intermediate deposition and re- 
suspension during riverine transport as potential processes leading to elevated ages.

Nevertheless, we regard these effects as minor considering the relatively flat geomorphology of the Congo basin ${ }^{14}$, the Congo's high discharge even under today's relatively dry conditions and the observation that similar age variations were also detected for wood fragments (Fig. 2a, 3, 4). Similarly, we rule out an influence of fossil OM contributions from sedimentary rocks as the molecular composition of the plant-wax fractions does not show any indication of thermally mature hydrocarbons (Fig. S1). Also, we infer that hydraulic sorting of fine and coarse particles carrying different radiocarbon contents ${ }^{5}$ cannot explain the observed ages as variations were also detected for the coarse $(>150 \mu \mathrm{m})$ wood fragments. As no large continental temperature variations in central Africa occurred during the Holocene ${ }^{19}$ (Fig. 2b), we also exclude temperature-driven changes in soil carbon turnover ${ }^{8,20}$ as an explanation for the observed age variations. Instead, we observe a strong relation to changes in continental hydrology. In particular, the trend towards greater ages from the Mid- to Late Holocene is paralleled by the aridification trend in central Africa ${ }^{21}$ (Fig. 2c). Towards the relatively dry present-day conditions all terrestrial OM fractions converge to their greatest initial ages. Comparing the radiocarbon contents of the molecular OM fractions to the hydrogen stable isotope compositions $(\delta \mathrm{D})$ of the $n-\mathrm{C}_{24}$ alcohol as a measure of rainfall intensity ${ }^{21}$, reveals that initial ages significantly increased when $\delta$ D values exceeded -145 \% VSMOW, indicating more arid conditions (Fig. 4). We thus conclude that the observed age trend was caused by release of previously stored OM from intermediate reservoirs controlled by changes in continental hydrology. Despite the high coverage of the Congo basin by tropical rainforest, even the deposited wood fragments follow this trend, suggesting a massive release of aged terrestrial OM. Disentangling the sedimentary TOC into pre-aged and fresh portions, i.e., directly from plants and aquatic organisms, reveals that about 30 to $70 \%$ of TOC is pre-aged during the Early to Mid-Holocene while this portion increases to 70 to $90 \%$ in the Late 
118 Holocene (Fig. 2d). Accumulation rates of pre-aged OC at GeoB6518-1 (Fig. 2e) are higher

119 during the latest Holocene than during the wetter Early to Mid-Holocene suggesting strongly

120 increased export fluxes of pre-aged OM by the Congo River under more arid conditions.

121 In order to identify the source of this large-scale old OM release, we analysed bacterial 122 signature lipids, i.e., bacteriohopanepolyols (BHPs) ${ }^{22,23}$, in sediments of GeoB6518-1. In 123 particular, we focused on 35-aminobacteriohopane-30,31,32,33,34-pentol (aminopentol), a

124 marker for aerobic methanotrophic bacteria predominant in wetlands ${ }^{22}$. Strong similarities of 125 the BHP signature in the Congo deep-sea fan and in wetland deposits ${ }^{22,23}$ (Fig. S2), coupled 126 with limited ${ }^{13} \mathrm{C}$ depletion of the BHPs, are consistent with aerobic oxidation of methane in a 127 terrestrial setting ${ }^{23}$ (see supplement). The aminopentol abundance profile in GeoB6518-1

128 (Fig. 2f) reveals a striking resemblance to the continental hydrologic changes ${ }^{21}$ (Fig. 2c). In 129 the humid Early Holocene, maximum abundance of aminopentol indicates largest wetland 130 extent in the Congo basin while its decreasing abundance suggests shrinking methane131 producing land cover during the Mid- to Late Holocene concomitant with increasing initial 132 ages of terrestrial OM (Fig. 2a). The observed threshold-like age trend with decreasing 133 rainfall intensity (Fig. 4) may point to an environmental tipping point with respect to wetland 134 extent depending on the regional geomorphology of the basin. The most likely candidate for 135 such a wetland system is the Cuvette Congolaise in the vast central depression of the Congo 136 basin at the confluence of several tributaries. It hosts one of the World's largest swamp forests 137 containing seasonally and permanently flooded wetlands with an estimated area of 360,000

$138 \mathrm{~km}^{2}$ (ref 24) (Fig. 1). These wetlands receive plant OM from local and upstream sources and 139 accumulate substantial amounts of $\mathrm{OM}^{25,26}$. Having remained largely unnoticed until 140 recently ${ }^{27,28}$, the modern central Congo basin is estimated to store at least $9 \mathrm{Pg} \mathrm{C}^{28}$ as a 141 consequence of water-saturated wetland soils inhibiting aerobic OM decomposition and 
142 instead resulting in (slower) anaerobic degradation emitting methane and other greenhouse $143 \operatorname{gases}^{29}$.

144 These various lines of evidence suggest that areas of OM storage under anoxic

145 conditions and associated methane production in the central Congo basin were more extended 146 during the more humid Early Holocene, serving as an important locus of temporary storage of

147 plant biomass. More rainfall in the basin led to higher transport of plant organic material into

148 the Cuvette Congolaise where it accumulated in the vast permanently flooded swamp forest

149 areas. In water-logged wetland soils remineralisation is diminished leading to enhanced

150 preservation and storage of OM. The elevated ages of refractory plant-wax lipids even under

151 wet, high discharge conditions point to additional processes, such as intermediate storage

152 during fluvial transport and /or deep soil erosion, affecting their ages. Upon aridification,

153 permanently flooded wetland areas with methane-producing land cover contracted and

154 previously anoxic deposits eroded triggering release of aged terrestrial OM. Additionally,

155 lower water levels caused erosion of deeper soil layers and previously deposited river beds.

156 Exposure of OM previously stored under anoxic conditions not only leads to release of

157 refractory organic components which are discharged but also of labile OM that is rapidly

158 oxidized. Thus, in addition to decreasing carbon sequestration due to wetland shrinkage, the

159 release and remineralisation of labile OM introduces a direct climatic feedback under more

160 arid conditions, the magnitude of which remains uncertain. Given that most tropical

161 watersheds, such as the Amazon ${ }^{27}$, contain extended wetland areas these findings have

162 profound global implications for the response of tropical terrestrial carbon inventories and

163 carbon cycle feedbacks upon hydrological changes. Impacted by natural climatic changes as

164 well as anthropogenic activities such as land use, deforestation, rising $\mathrm{CO}_{2}$ levels and

165 associated effects on climate ${ }^{30}$, any changes in tropical wetland extent may thus exert a direct 
166 climatic feedback. Presently, such effects are underestimated in global climate assessments ${ }^{30}$

167 and must be considered to more accurately assess the response of terrestrial carbon cycle

168 dynamics to future climatic change.

169 
1711 Raymond, P. A. \& Bauer, J. E. Riverine export of aged terrestrial organic matter to the 172 North Atlantic Ocean. Nature 409, 497-500 (2001).

1732 Hilton, R. G. et al. Climatic and geomorphic controls on the erosion of terrestrial 174 biomass from subtropical mountain forest. Glob. Biogeochem. Cycles 26,

175 doi:10.1029/2012gb004314 (2012).

1763 Hedges, J. I. et al. Organic carbon-14 in the Amazon River system. Science 231, 1129$177 \quad 1131(1986)$.

1784 Martin, E. E. et al. Age of riverine carbon suggests rapid export of terrestrial primary 179 production in tropics. Geophys.Res. Lett. 40, 5687-5691 (2013).

1805 Spencer, R. G. M. et al. An initial investigation into the organic matter 181 biogeochemistry of the Congo River. Geochim. Cosmochim. Acta 84, 614-627 (2012).

1826 Galy, V. \& Eglinton, T. Protracted storage of biospheric carbon in the Ganges-

183 Brahmaputra basin. Nature Geosci. 4, 843-847 (2011).

1847 Marwick, T. R. et al. The age of river-transported carbon: A global perspective. Glob. $185 \quad$ Biogeochem. Cycles 29, GB004911 (2015).

1868 Carvalhais, N. et al. Global covariation of carbon turnover times with climate in 187 terrestrial ecosystems. Nature 514, 213-217 (2014).

1889 Huang, T. H., Fu, Y. H., Pan, P. Y. \& Chen, C. T. A. Fluvial carbon fluxes in tropical 189 rivers. Curr. Opin. Environ. Sustain. 4, 162-169 (2012).

19010 Schluenz, B. \& Schneider, R. R. Transport of terrestrial organic carbon to the oceans 191 by rivers: re-estimating flux- and burial rates. Int. J. Earth Sci. 88, 599-606 (2000).

19211 Blair, N. E., Leithold, E. L. \& Aller, R. C. From bedrock to burial: the evolution of 193 particulate organic carbon across coupled watershed-continental margin systems. Mar. 194 Chem. 92, 141-156 (2004). 
19512 Kusch, S., Rethemeyer, J., Schefuß, E. \& Mollenhauer, G. Controls on the age of

196 vascular plant biomarkers in Black Sea sediments. Geochim. Cosmochim. Acta 74,

$197 \quad 7031-7047(2010)$.

19813 Drenzek, N. J. et al. A new look at old carbon in active margin sediments. Geology 37,

$199 \quad 239-242(2009)$.

20014 Runge, J. The Congo River, Central Africa. in Large Rivers: Geomorphology and

201 Management (ed A. Gupta) 293-309 (Wiley, 2007).

20215 Coynel, A., Seyler, P., Etcheber, H., Meybeck, M. \& Orange, D. Spatial and seasonal

203 dynamics of total suspended sediment and organic carbon species in the Congo River.

204 Glob. Biogeochem. Cycles 19, GB4019 (2005).

20516 Laraque, A., Bricquet, J. P., Pandi, A. \& Olivry, J. C. A review of material transport

206 by the Congo River and its tributaries. Hydrol. Process. 23, 3216-3224 (2009).

20717 Huang, Y., Li, B., Bryant, C., Bol, R. \& Eglinton, G. Radiocarbon dating of aliphatic

208 hydrocarbons: a new approach for dating passive-fraction carbon in soil horizons. Soil

209 Sci. Soc. Am. J. 63, 1181-1187 (1999).

21018 Weijers, J. W. H., Schouten, S., Schefuss, E., Schneider, R. R. \& Sinninghe Damsté, J.

211 S. Disentangling marine, soil and plant organic carbon contributions to continental

212 margin sediments: A multi-proxy approach in a 20,000 year sediment record from the

213 Congo deep-sea fan. Geochim. Cosmochim. Acta 73, 119-132 (2009).

21419 Weijers, J. W. H., Schefuss, E., Schouten, S. \& Sinninghe Damsté, J. S. Coupled

215 thermal and hydrological evolution of tropical Africa over the last deglaciation.

$216 \quad$ Science 315, 1701-1704 (2007).

21720 Davidson, E. A. \& Janssens, I. A. Temperature sensitivity of soil carbon

218 decomposition and feedbacks to climate change. Nature 440, 165-173 (2006). 
21921 Schefuß, E., Schouten, S. \& Schneider, R. R. Climatic controls of Central African

220 hydrology during the last 20,000 years. Nature 437, 1003-1006 (2005).

22122 Spencer-Jones, C. L. et al. Bacteriohopanepolyols in tropical soils and sediments from 222 the Congo River catchment area. Org. Geochem. 89-90, 1-13 (2015).

22323 Talbot, H. M. et al. Variability in aerobic methane oxidation over the past 1.2 Myrs 224 recorded in microbial biomarker signatures from Congo fan sediments. Geochim. $225 \quad$ Cosmochim. Acta 133, 387-401 (2014).

22624 Bwangoy, J. R. B., Hansen, M. C., Roy, D. P., De Grandi, G. \& Justice, C. O. Wetland 227 mapping in the Congo Basin using optical and radar remotely sensed data and derived $228 \quad$ topographical indices. Remote Sens. Environ.t 114, 73-86 (2010).

22925 Mitsch, W. J. et al. Wetlands, carbon, and climate change. Landsc. Ecol. 28, 583-597 $230 \quad$ (2013).

23126 Kayranli, B., Scholz, M., Mustafa, A. \& Hedmark, A. Carbon storage and fluxes 232 within freshwater wetlands: a critical review. Wetlands 30, 111-124 (2010).

23327 Keddy, P. A. et al. Wet and wonderful: The World's largest wetlands are conservation 234 priorities. Bioscience 59, 39-51 (2009).

23528 Joosten, H. \& Tapio-Biström, M.-L. Peatlands - guidance for climate change 236 mitigation through conservation, rehabilitation and sustainable use. in Mitigation of 237 climate change in agriculture Vol. 5100 pp. (Food and Agriculture Organization of 238 the United Nations/Wetlands International, Rome, 2012).

23929 Borges, A. V. et al. Globally significant greenhouse-gas emissions from African 240 inland waters. Nature Geosci. 8, 637-642 (2015).

24130 Arneth, A. et al. Terrestrial biogeochemical feedbacks in the climate system. Nature 242 Geosci. 3, 525-532(2010). 
245 Correspondence and requests for materials

246 Correspondence and requests for materials should be addressed to E.S.

247 (eschefuss@marum.de).

\section{Acknowledgements}

250 We thank J. M. Hayes, G. Mollenhauer, T. Goldhammer, M. Zabel, T. Wagner and M. Schulz

251 for discussions. M. Luttmann, H. Buschhoff, D. Montluçon, F. Sidgwick, P. Green and S.

252 Sylva are thanked for analytical support. We thank the staff at all involved radiocarbon dating

253 facilities for their invaluable efforts. This study was supported by the Deutsche

254 Forschungsgemeinschaft (grants SCHN 621/3-3, RU 458/29-3, GR 1845/2-3, SCHE 903/1),

255 the US National Science Foundation (grant OCE-0137005), a Starting Grant from the

256 European Research Council (ERC) awarded to HMT for project AMOPROX (No. 258734)

257 and grants ICM-NC120066 and FONDAP15110009 to RDP-H. This work was supported by

258 the DFG Research Center/Cluster of Excellence 'The Ocean in the Earth System' at MARUM

259 - Center for Marine Environmental Sciences, University of Bremen.

\section{Author contributions}

261 E.S., T.I.E., J.R., P.M.G., and R.R.S. designed the study. Analytical work was performed by

262 E.S., C.L.S.-J., H.M.T., J.R., P.M.G., and R.D.P.-H.. E.S. wrote the manuscript approved by 263 all co-authors. 
Competing financial interests

266 The authors declare no competing financial interests.

267 


\section{Figure captions}

Figure 1: The Congo River basin in central Africa. Redrawn after ref 14 . Light

271 grey areas are lakes. Dark grey area is the present-day extent of swamp forest in the

272 Cuvette Congolaise ${ }^{24,27}$. Black star offshore the Congo River mouth is sampling

273 location of sediment core GeoB6518-1.

Figure 2: OM ages offshore the Congo River and central African environmental changes. a) Offsets in radiocarbon contents versus the past atmosphere and apparent initial ages at time of deposition (brown: wood pieces, green: $n-C_{24}$ alcohol, grey: $n$-alkanes, blue: TOC), error bars show analytical uncertainty propagated with

$\Delta^{14} C_{\text {atm }}$ uncertainty, b) estimates of past temperatures $\left.{ }^{19}, c\right)$ hydrogen stable isotope

280 composition of $n-C_{29}$ alkane ${ }^{21}$ reflecting rainfall intensity, green dots: $n-C_{24}$ alcohol, error bars show analytical uncertainty, d) TOC disentangled in fresh (green) and preaged (brown) portions, e) accumulation rate of pre-aged $\mathrm{OC}, \mathrm{f}$ ) abundance of aminopentol reflecting extent of methane-producing landcover ${ }^{23}$.

Figure 3: Correlation of age variations between different OM fractions. Initial radiocarbon offsets are strongly correlated $(r=0.93, p<0.05)$ for $n$-alkanes (grey dots) and $n-C_{24}$ alcohol indicating that both are affected by the same continental retention processes. Error bars show analytical uncertainty propagated with $\Delta^{14} \mathrm{C}_{\mathrm{atm}}$ uncertainty. Radiocarbon offsets are more negative for $n$-alkanes than for $n-C_{24}$

290 alcohol indicating that $n$-alkanes are more refractory than $n-C_{24}$ alcohol. Radiocarbon 
291 offsets of wood fragments (brown dots) show no correlation to initial radiocarbon

292 offsets of $n-C_{24}$ alcohol except for the lowest initial radiocarbon offsets, i.e., highest

293 apparent initial ages.

294

295 Figure 4: Relation between rainfall intensity and OM ages. Comparison of initial

296 radiocarbon offsets of wood pieces (brown dots) and $n-C_{24}$ alcohol (green dots) with

297 hydrogen isotope compositions of $n-C_{24}$ alcohol. Error bars show analytical

298 uncertainty propagated with $\Delta \Delta^{14} C_{\text {atm }}$ uncertainty. Initial radiocarbon offsets of $n$ -

299 alkanes (Fig. 3) and TOC show the same trend but are omitted for clarity. Where the

300 hydrogen stable isotope composition of the $n-C_{24}$ alcohol exceeds $-145 \%$ VSMOW,

301 initial radiocarbon offsets of all OM fractions become more negative indicating

302 release of previously stored, i.e., pre-aged, material. 
304 Online Content Methods are available in the online version of the paper; references unique to

305 this section appear only in the online paper. Source data and additional display items are in 306 the Supplementary Information.

\section{Methods}

Age model of GeoB6518-1. The age model of GeoB6518-1 is based on AMS dating of mixed planktonic foraminifera containing Globigerinoides ruber (white), Globigerinoides sacculifer

311 and Orbulina universa isolated from sediments by wet-sieving $(>150 \mu \mathrm{m})$ and picking.

312 Fractions were cleaned with $\mathrm{H}_{2} \mathrm{O}$ and $15 \% \mathrm{H}_{2} \mathrm{O}_{2}$, carbonate was converted to $\mathrm{CO}_{2}$ with $100 \%$

313 phosphoric acid and subsequently catalytically reduced to graphite for AMS measurement of

314 radiocarbon $\left({ }^{14} \mathrm{C}\right.$ ) contents. ${ }^{14} \mathrm{C}$ contents were corrected for blank effects ${ }^{31}$ (Table S1). Most

315 foraminiferal ages were reported earlier ${ }^{21}$ and re-calibrated to calendar ages in this study. An

316 additional age point was added for depth $128-138 \mathrm{~cm}$. A further sample $(78-88 \mathrm{~cm})$ was lost

317 during AMS measurement. All dates were calibrated with Calib7.0 using the Marine13

318 radiocarbon age calibration and no regional and temporal offset in the reservoir age

319 correction $^{32}$. We set the mid-point of the sampling interval to the mean age of the calibrated 2-

$320 \sigma$ age interval. Because the uppermost sample $(5-15 \mathrm{~cm})$ contains radiocarbon from

321 atmospheric nuclear weapons testing (post-1950 age), we set the core-top to zero age and did

322 not regard the uppermost sample as an age tie-point. Ages of individual samples between tie-

323 points were linearly interpolated.

324 Radiocarbon dating of total organic carbon and wood fragments. Total organic carbon

325 (TOC) contents (Tables S2, S3, S4) were determined by combustion of ground and de-

326 carbonated sediment samples at $1050^{\circ} \mathrm{C}$ using a Leco CS230 Carbon-Sulphur analyser. The

327 relative precision of the measurements, based on triplicate analyses was better than $1.8 \%$

328 relative standard deviation. For ${ }^{14} \mathrm{C}$ analyses of TOC, ground sediments were treated with $1 \%$ 
hydrochloric acid to remove carbonates and subsequently freeze-dried. Samples were

330 combusted with copper oxide and silver wool in quartz tubes and the $\mathrm{CO}_{2}$ released converted

331 into graphite for AMS measurement. ${ }^{14} \mathrm{C}$ contents were corrected for blank contributions ${ }^{31}$.

332 Several microscopic wood fragments $(>150 \mu \mathrm{m})$ were isolated from each sediment sample

333 under a binocular microscope. After acid-base-acid treatment to remove humic materials they

334 were combusted and the resulting $\mathrm{CO}_{2}$ catalytically converted to graphite for ${ }^{14} \mathrm{C}$

335 measurement by AMS. ${ }^{14} \mathrm{C}$ contents were corrected for blank contributions and small sample

336 size $^{33}$. Two samples $(253-258 \mathrm{~cm}, 453-458 \mathrm{~cm})$ yielded ages of wood pieces younger than

337 depositional ages. This may be due to slight variations in the marine reservoir age. Therefore,

338 their corresponding ${ }^{14} \mathrm{C}$ data were omitted from further calculations. As these data derive from

339 deglacial and early Holocene samples, omitting them from discussion has no influence on the

340 observation of increasing wood ages towards the Late Holocene. Data are listed in

341 supplementary Table S2.

342 Radiocarbon dating of plant-waxes. Sediments were Soxhlet-extracted with a 93:7 mixture

343 of dichloromethane and methanol and afterwards saponified with $0.5 \mathrm{M} \mathrm{KOH}$ in methanol.

344 After re-extraction with hexane, neutral fractions were separated by liquid chromatography

345 over silica-gel $\left(\mathrm{SiO}_{2}\right)$ columns into apolar, ketone and polar fractions by elution with hexane,

346 hexane/dichloromethane and methanol, respectively. Elemental sulphur was removed from

347 apolar fractions using activated copper before branched and cyclic lipids were removed by

348 urea adduction. Unsaturated compounds were removed by liquid chromatography over

$349 \mathrm{AgNO}_{3}$-impregnated $\mathrm{SiO}_{2}$ columns. $n$-Alkane fractions were quantified against external

350 alkane standards via gas chromatography-flame ionisation detection (GC-FID) and

351 quantitatively transferred into quartz tubes, combusted and the produced $\mathrm{CO}_{2}$ catalytically

352 converted into graphite before AMS measurement. Alcohol fractions were acetylated with

353 acetic anhydride with known isotopic composition and treated by urea adduction and $\mathrm{AgNO}_{3-}$

$354 \mathrm{SiO}_{2}$ chromatography. After GC-FID quantification, the $n-\mathrm{C}_{24}$ alcohol was isolated by

355 preparative gas chromatography using a gas chromatograph coupled to a preparative fraction

356 collector $^{34}$. After cleaning the isolated compounds by silica-gel column chromatography, 
357 aliquots were checked for purity by GC-FID and samples were transferred into quartz tubes, 358 combusted and the produced $\mathrm{CO}_{2}$ catalytically converted into graphite for AMS measurement.

$359{ }^{14} \mathrm{C}$ contents were corrected for modern and fossil blank contributions to small samples by 360 error propagation. $n$-Alcohol radiocarbon contents were corrected for carbon contribution 361 from the added acetate group by mass balance calculation. The hydrogen isotope ratio of the $362 n-\mathrm{C}_{24}$ alcohol was measured using a mass spectrometer connected to a gas chromatograph via 363 a pyrolysis interface against $\mathrm{H}_{2}$ reference gas. The $\mathrm{H}_{3}$-factor was measured daily and was $<6$ $364 \mathrm{ppm} \mathrm{mV}^{-1}$ with variability from day to day of less than $0.2 \mathrm{ppm} \mathrm{mV}^{-1}$. Analyses of an external 365 alkane standard (“Arndt B", Arndt Schimmelmann, Indiana State University) revealed a mean 366 absolute precision of $3 \%$ and an accuracy of $0 \%$. Precision of $\delta \mathrm{D}$ composition of the $n-\mathrm{C}_{24}$ 367 alcohol is based on replicate analyses. The $\delta \mathrm{D}$ value of the $n-\mathrm{C}_{24}$ alcohol was corrected for the 368 added acetate group by mass-balance calculation. Data are listed in supplementary Table S2.

369 Calculation of initial $\Delta \Delta^{\mathbf{1 4}} \mathbf{C}$ and apparent initial ages. If the depositional age is known, i.e., 370 the calendar age derived from the planktonic foraminifera, it is possible to calculate the initial 371 radiocarbon content from the measured fraction modern (Fm) of all OM AMS results (Table 372 S2) using the following equation ${ }^{35}$ : $\Delta^{14} \mathrm{C}_{\text {inital }}=\left(\mathrm{Fm} \mathrm{e}^{(\lambda \mathrm{t})}-1\right) \times 1000 \%$

$374 \quad F m$ is the measured fraction modern, $\lambda$ is the decay constant $\left(1 / 8267\right.$ years $\left.{ }^{-1}\right)$ of ${ }^{14} \mathrm{C}$, and $375 \mathrm{t}$ is time since deposition in years. For the sampling depth for which the foraminiferal ${ }^{14} \mathrm{C}$ 376 sample was lost $(78-88 \mathrm{~cm})$, we assumed the depth-integrated age from the linear 377 interpolation ( $2492 \pm 354$ calendar years) as depositional age in order to be able to calculate 378 initial radiocarbon contents of different OM fractions.

379 The offset of the initial radiocarbon contents of OM fractions to that of the past 380 atmosphere $\left(\Delta^{14} \mathrm{C}_{\text {atm }}\right)$ is calculated as: 


$$
\Delta \Delta^{14} \mathrm{C}_{\text {initial }}=\Delta^{14} \mathrm{C}_{\text {initial }}-\Delta^{14} \mathrm{C}_{\text {atm }}
$$

$382 \Delta \Delta^{14} \mathrm{C}$ values for the past atmosphere are based on time-integrated values derived from the

383 Intcal13 southern Hemisphere atmospheric data ${ }^{36}$. For the uppermost sample $(5-15 \mathrm{~cm})$,

384 which contains nuclear bomb-derived radiocarbon, we obtained the atmospheric ${ }^{14} \mathrm{C}$ content

385 from the atmospheric measurements ${ }^{37}$ at the year of core retrieval (year $2000 \mathrm{CE}$ ). The

386 associated error for this sample was obtained from the corresponding ages of the sample depth

387 interval ${ }^{37} \cdot \Delta^{14} \mathrm{C}_{\text {atm }}$ values are given in Table $\mathrm{S} 2$.

In order to provide ages instead of only radiocarbon contents, the apparent initial (conventional) ${ }^{14} \mathrm{C}$ age is calculated from the initial radiocarbon content ${ }^{35}$ :

$$
{ }^{14} \mathrm{C} \text { age }=-8033 \times \ln \left[\left(1+\Delta \Delta^{14} \mathrm{C}_{\text {initial }} / 1000\right) /\left(1+\Delta \Delta^{14} \mathrm{C}_{\text {atm }} / 1000\right)\right]{ }^{14} \mathrm{C} \text { years }
$$

with $\Delta^{14} \mathrm{C}_{\text {initial }}$ the initial radiocarbon content of each OM fraction and $\Delta^{14} \mathrm{C}_{\text {atm }}$ the atmospheric

392 radiocarbon content at the time of deposition.

393 Estimates of pre-aged OC fractions and accumulation rates. To provide estimates of the

394 relative and absolute release of previously deposited, i.e., aged, organic matter, we conducted

395 a mass-balance calculation using the amount and initial ${ }^{14} \mathrm{C}$ contents of TOC and the initial

$396{ }^{14} \mathrm{C}$ contents of plant-wax $n$-alkanes and of the past atmosphere (Table S2) to disentangle

397 fresh from pre-aged portions within TOC.

$$
\text { Pre-aged OC } \%=\text { TOC } \% \times\left(\Delta^{14} \mathrm{C}_{\text {TOC_initial }}-\Delta^{14} \mathrm{C}_{\text {atm }}\right) /\left(\Delta^{14} \mathrm{C}_{\text {alkanes_initial }}-\Delta^{14} \mathrm{C}_{\text {atm }}\right)
$$

with TOC $=$ TOC content of sample, $\Delta{ }^{14} \mathrm{C}_{\mathrm{TOC}}$ _initial $=$ decay-corrected past ${ }^{14} \mathrm{C}$ contents of

400 TOC, $\Delta \Delta^{14} \mathrm{C}_{\text {atm }}=$ past atmospheric ${ }^{14} \mathrm{C}$ contents, $\Delta{ }^{14} \mathrm{C}_{\text {alkanes _initial }}=$ decay-corrected past ${ }^{14} \mathrm{C}$

401 contents of $n$-alkanes (all data in Table S2).

402 The $n$-alkanes as oldest dated fractions in all sediment samples were taken as representing the 403 age of released organic material acknowledging that also these compounds contain fresh 404 portions, i.e., directly derived from plants. As TOC also contains aquatic OM of modern 405 origin albeit in small amounts ${ }^{18}$ which adds to the estimated fresh portion of TOC this results 406 in a slight over-estimation of the fresh, directly plant-derived OM. Additionally, it must be 
407 considered that the labile OM, which is released from wetland deposits, is rapidly oxidised

408 (see main text) and will not be preserved in sedimentary archives. The estimates of pre-aged

409 sedimentary TOC portions therefore reflect minimum estimates of released organic matter.

410 To evaluate if not only the relative portion of pre-aged OC in the sedimentary archive

411 increased but also the absolute flux of pre-aged material, we calculated the accumulation rate

412 of pre-aged OC in the sediment given by the percentage of pre-aged OC multiplied by the

413 bulk sediment accumulation rate (bulk accumulation rate $=$ sedimentation rate $\mathrm{x}$ dry bulk

414 density). While we acknowledge that the accumulation rates of all sedimentary components

415 are strongly dominated by the sedimentation rate (see supplementary Fig. S3d) it is clear that

416 the accumulation rate of pre-aged $\mathrm{OC}$ in the latest Holocene exceeds its values during the

417 Early and Mid-Holocene suggesting that also the export flux of pre-aged OC by the Congo

418 River is higher under most arid conditions.

419 Influence of fossil plant-wax contributions. In order to evaluate if the higher plant-wax ages

420 were caused by variable admixture of fossil, i.e., petrogenic, contributions, we calculated the 421 Carbon Preference Index (CPI) ${ }^{38}$ :

$\mathrm{CPI}=0.5 \times\left(\Sigma\left(\mathrm{C}_{\mathrm{i}}+\mathrm{C}_{\mathrm{i}+2}+. .+\mathrm{C}_{\mathrm{n}}\right) / \Sigma\left(\mathrm{C}_{\mathrm{i}-1}+\mathrm{C}_{\mathrm{i}+1}+. .+\mathrm{C}_{\mathrm{n}-1}\right)+\Sigma\left(\mathrm{C}_{\mathrm{i}}+\mathrm{C}_{\mathrm{i}+2}+. .+\mathrm{C}_{\mathrm{n}}\right) / \Sigma\left(\mathrm{C}_{\mathrm{i}+1}+\right.\right.$

$\left.\left.\mathrm{C}_{\mathrm{i}+3}+. .+\mathrm{C}_{\mathrm{n}+1}\right)\right)$

where $i$ is the number of carbon atoms. CPI was calculated for $n$-alkanes ranging from $i=27$

to $\mathrm{n}=33$ and for $n$-alcohols from $\mathrm{i}=22$ to $\mathrm{n}=28$. Terrestrial higher plants produce long-chain $n$-alkanes with elevated CPI values ${ }^{38}$ whereas thermally altered and extensively degraded organic matter contains $n$-alkanes with a CPI around 1 (ref 39). CPI indices of $n$-alkanes and $n$-alcohols do not correlate with their initial radiocarbon content (see supplementary Fig. S1). Therefore, we rule out that the observed age variations reflect contributions of petrogenic material from eroded sedimentary rocks.

431 Bacteriohopanepolyols. Full details of the BHP methodology were published previously ${ }^{23,40}$.

432 Briefly, total lipids were extracted from freeze-dried sediments using a modified Bligh and 
433 Dyer technique. One third of the extract was then acetylated to yield acetylated BHPs, which

434 were analysed by reversed-phase high performance liquid chromatography-atmospheric

435 pressure chemical ionisation-mass spectrometry (HPLC-APCI-MS ${ }^{\mathrm{n}}$ ). Semi-quantification of

436 BHP contents was achieved employing the characteristic base peak areas of individual BHPs

437 in mass chromatograms relative to the $\mathrm{m} / \mathrm{z} 345$ mass chromatogram base peak area of the

438 acetylated $5 \alpha$-pregnane-3 $\beta, 20 \beta$-diol internal standard. Averaged relative response factors

439 relative to the internal standard, determined from a suite of acetylated BHP standards, were

440 used to adjust the BHP peak areas. Typical error in absolute quantification was $\pm 20 \%$, based

441 on selected replicate analyses and BHP standards of known concentration ${ }^{23,40}$. BHP data are

442 in supplementary tables S3, S4 and supplementary figure S2.

443 Data availability. Data generated in this study are available from the PANGAEA database

444 (https://doi.pangaea.de/10.1594/PANGAEA.862021). 
$44731 \quad$ Nadeau, M.-J. et al. Sample throughput and data quality at the Leibniz-Labor AMS

448 facility. Radiocarbon 40, 239-245 (1998).

44932 Reimer, P. J. et al. INTCAL13 and MARINE13 radiocarbon age calibration curves 0-

$450 \quad 50,000$ years cal BP. Radiocarbon 55, 1869-1887 (2013).

45133 Santos, G. M., Southon, J. R., Griffin, S., Beaupre, S. R. \& Druffel, E. R. M. Ultra

452

453

454

455

456

457

458

459

460

461

462

463

464

465

466

467

468 small-mass AMS C-14 sample preparation and analyses at KCCAMS/UCI Facility. Nucl. Instrum. Methods Phys. Res. B 259, 293-302 (2007).

34 Eglinton, T. I., Aluwihare, L. I., Bauer, J. E., Druffel, E. R. M. \& McNichol, A. P. Gas chromatographic isolation of individual compounds from complex matrices for radiocarbon dating. Anal. Chem. 68, 904-912 (1996).

35 Stuiver, M. \& Polach, H. A. Discussion: Reporting of ${ }^{14} \mathrm{C}$ data. Radiocarbon 19, 355363 (1977).

36 Hogg, A. G. et al. SHCAL13 southern hemisphere calibration, 0-50,000 years cal BP. Radiocarbon 55, 1889-1903 (2013).

37 Levin, I., Kromer, B. \& Hammer, S. Atmospheric Delta (CO2)-C-14 trend in Western European background air from 2000 to 2012. Tellus Ser. B 65, 20092 (2013).

38 Eglinton, G. \& Hamilton, R. J. Leaf epicuticular waxes. Science 156, 1322-1335 (1967).

39 Peters, K. E. \& Moldowan, J. M. The Biomarker Guide: Interpreting Molecular Fossils in Petroleum and Ancient Sediments. (Prentice-Hall, 1993).

40 van Winden, J. F. et al. Bacteriohopanepolyol signatures as markers for methanotrophic bacteria in peat moss. Geochim. Cosmochim. Acta 77, 52-61 (2012). 


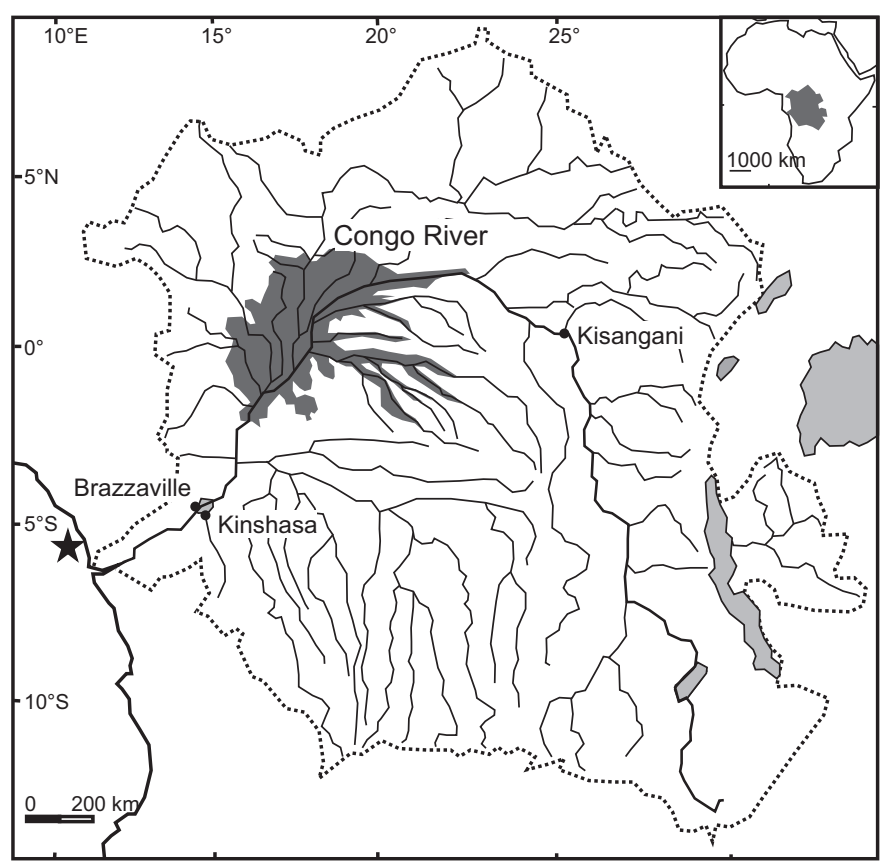



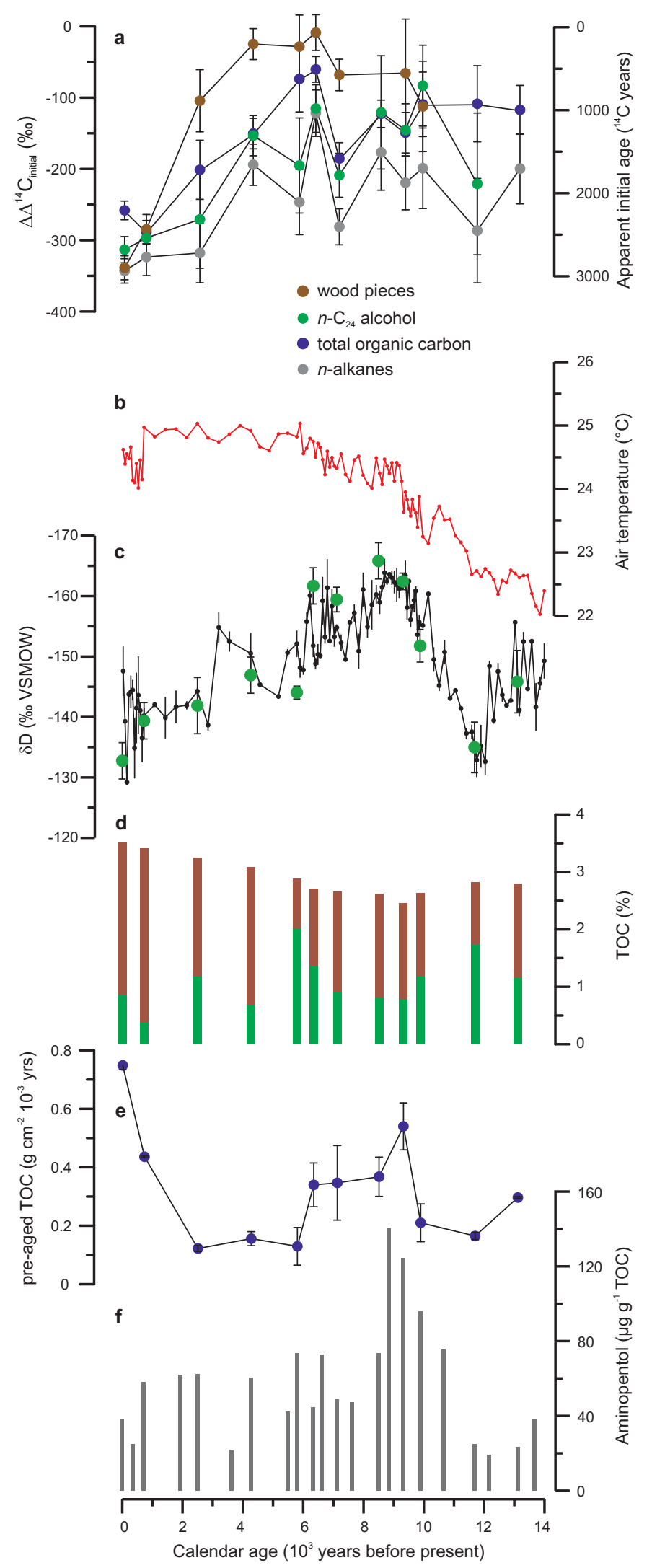


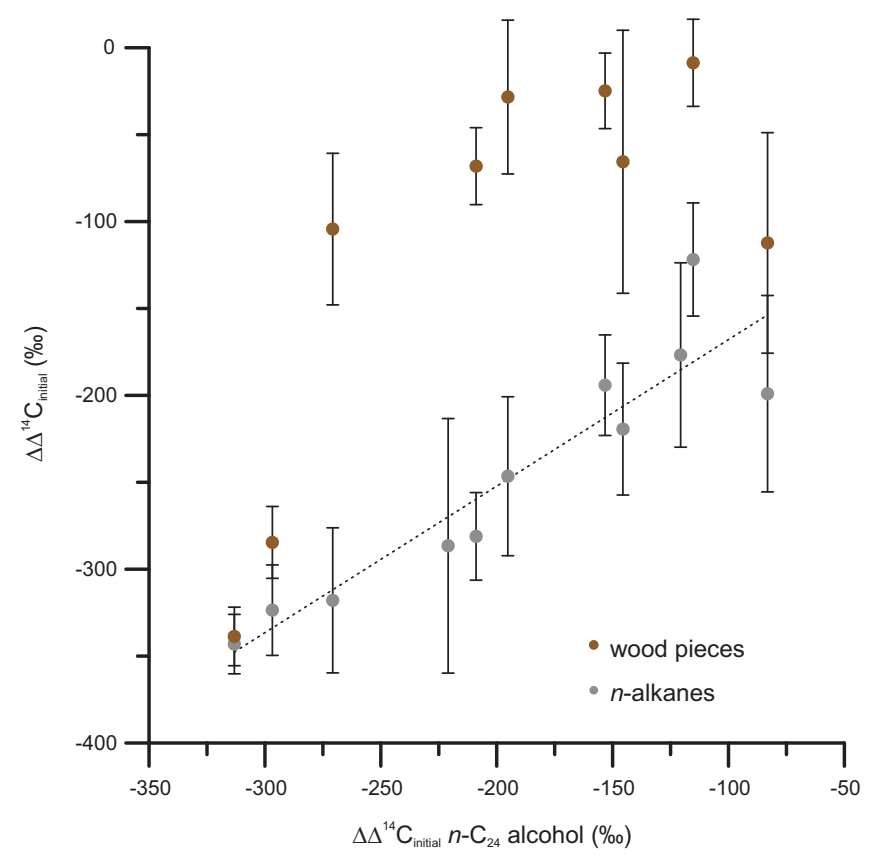




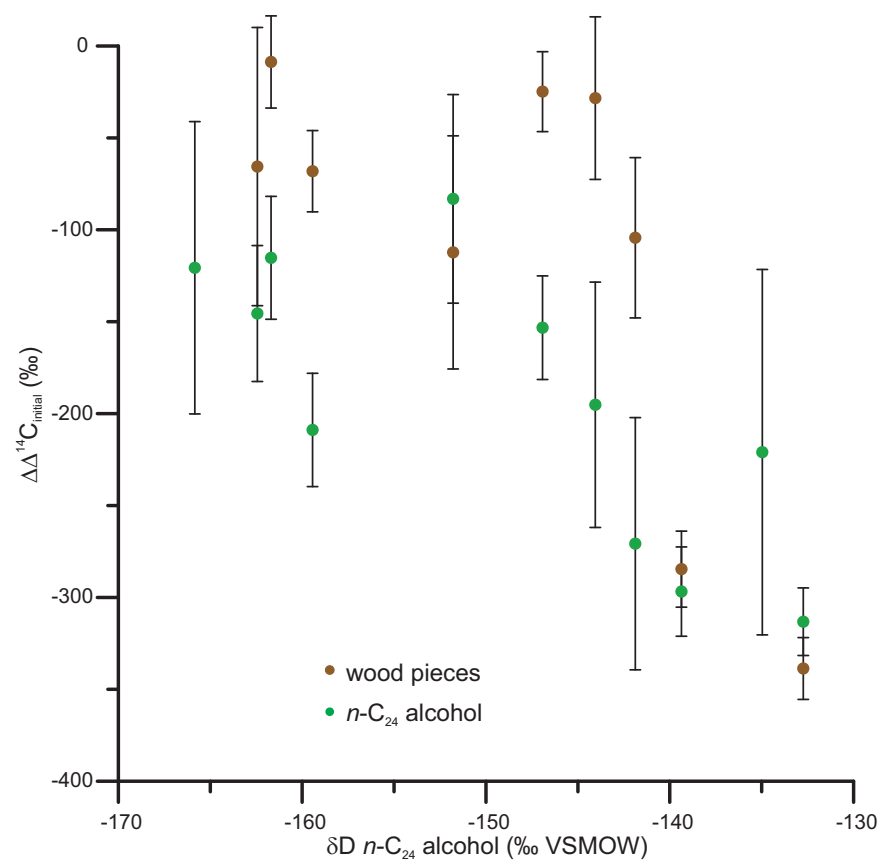




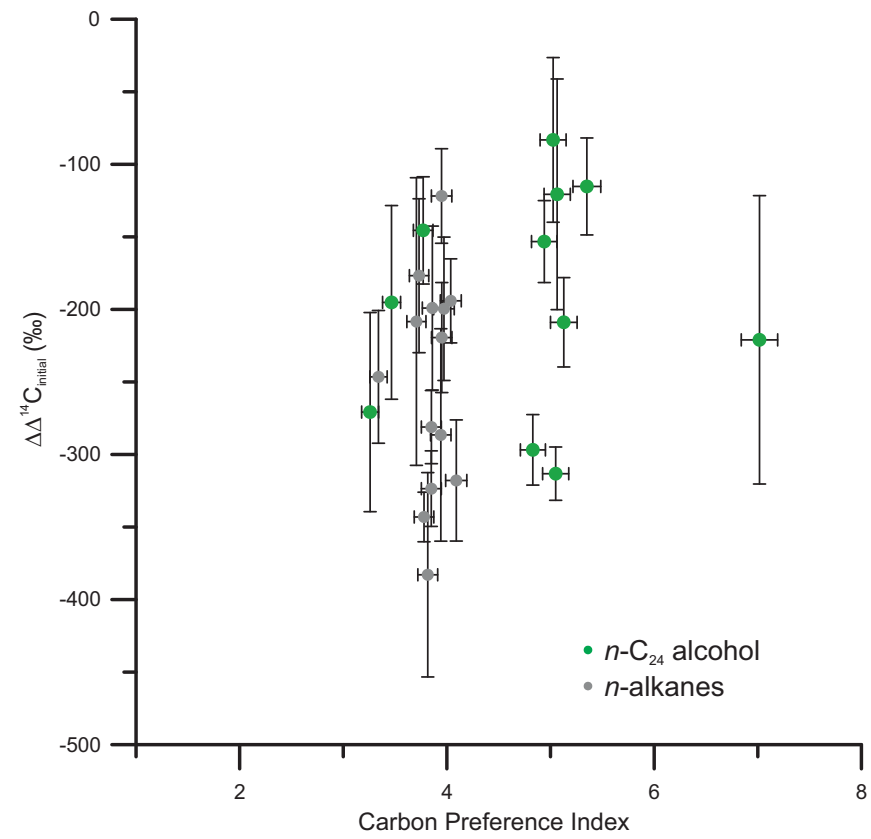

Figure S1: Absence of fossil OM influences on OM ages. Initial radiocarbon offsets of $n$-alkanes (grey dots) and $n-\mathrm{C}_{24}$ alcohol (green dots) versus their respective Carbon-Preference-Indices (CPI), error bars show analytical uncertainty propagated with $\Delta^{14} \mathrm{C}_{\mathrm{atm}}$ uncertainty. 


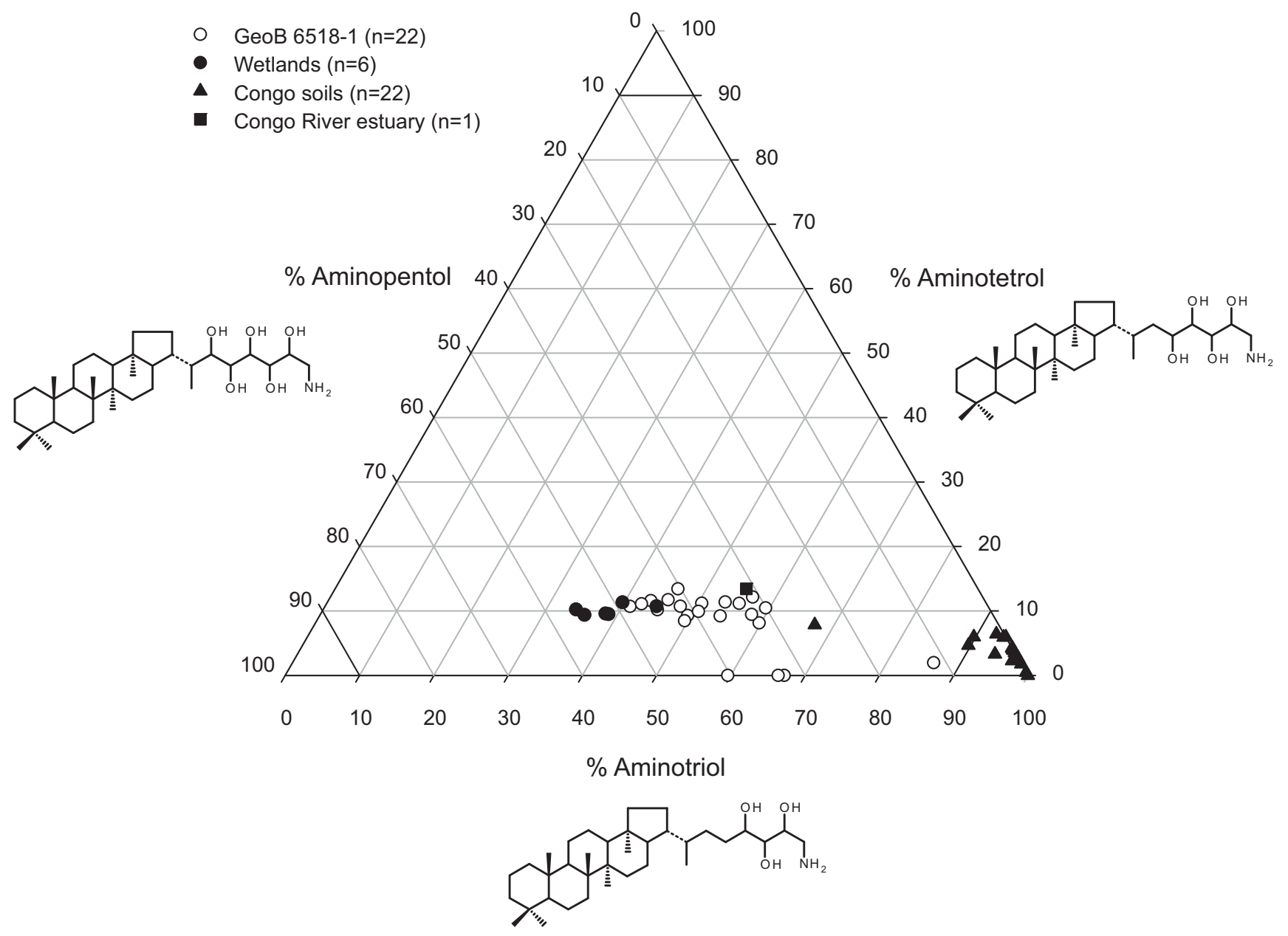

Figure S2: BHP compositions of Congo wetland deposits, soils, and sediments. Ternary plot of the relative abundance of aminoBHP compounds (aminotriol, aminotetrol and aminopentol) present in core GeoB6518-1 (22 samples; this study), the Congo estuarine sediment, 6 wetland sediments and 22 soils from the Congo (data from ref 23). 


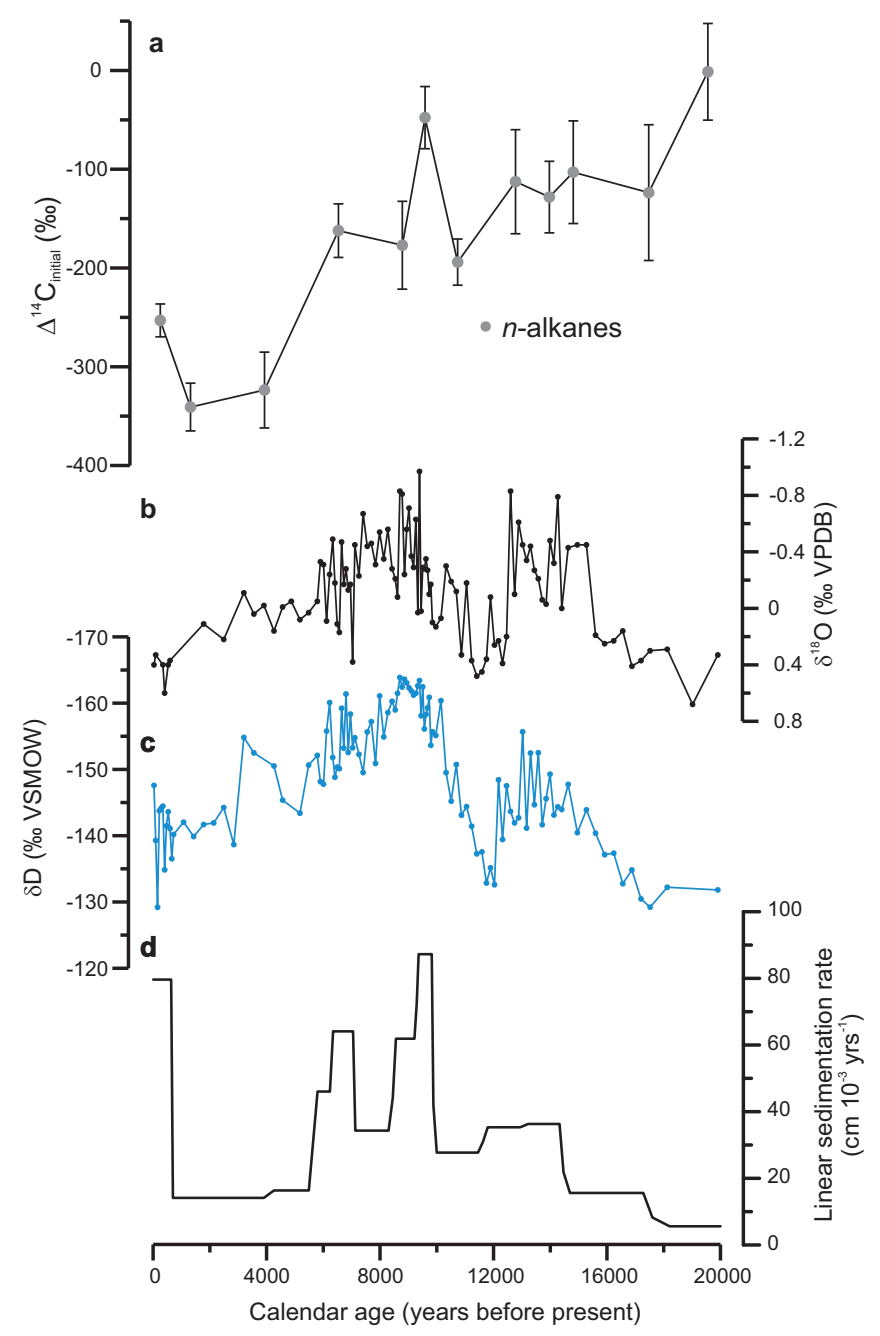

Figure S3: Independence of OM ages, proxy records and sedimentation. Comparison of initial radiocarbon contents of $n$-alkanes in GeoB6518-1 (a) with Congo River runoff reconstructions based on oxygen isotope compositions of planktonic foraminifera (b, black), compound-specific plant-wax based reconstruction of rainfall intensity in the Congo basin ${ }^{21}$ (c, blue) and linear sedimentation rate of GeoB6518-1 (d). Error bars in a) reflect analytical uncertainty. 